\title{
The need for new mechanisms to ensure research integrity
}

$\mathrm{T}$ he honesty, rigour and professionalism of scientists are the essence of research integrity. But we increasingly hear of breaches, ranging from ethical and professional lapses to outright fraud. All undermine public confidence in science and medicine - and in researchers and health professionals.

There are plenty of well-publicized examples of serious research misconduct. Korean scientist Hwang Woo Suk was hailed as a national hero before the discovery that his research on cloning human cells was fabricated. ${ }^{1}$ Montréal researcher Roger Poisson falsified information to recruit ineligible patients for a trial of treatment for breast cancer, which led to widespread doubt about whether lumpectomy plus radiotherapy was truly equivalent to mastectomy. ${ }^{2}$ René Lafrèniere, former head of surgery at the University of Calgary, plagiarized several passages of a paper - ironically on medical ethics - setting a hideous example at a time when universities struggle to combat plagiarism by students. ${ }^{3}$ Calgary scientist and former Canada Research Chair Daniel Kwok misappropriated $\$ 150000$ in taxpayer-funded grant money from the Natural Sciences and Engineering Research Council of Canada for personal and household items. ${ }^{4}$ Just recently, 89 articles by German anesthesiology researcher Joachim Boldt were retracted because he failed to obtain ethics approval, forcing re-examination of the evidence base for the use of commonly used colloids in acute care and surgery. ${ }^{5}$

There are other even more common infractions such as conflicts of interest, misrepresentation of authorship and manipulation of reports. Solid data on the frequency of such events are not readily available, but as journal editors, we encounter them all too often.

Stopping misconduct begins with detecting it, which is usually done by journal editors and peer reviewers, or by other scientists or whistle-blowers. If misconduct is discovered by a journal, then the authors are questioned; if suspicions remain, we can request an investigation. A similar approach is used by institutions if misconduct is reported before submission to a journal. Unfortunately, investigations are usually done by researchers' own institutions, despite the inherent conflict of interest of doing so when they are also concerned with academic reputation, high-profile faculty and the imperative to keep grant and sponsorship money flowing.

Scientific journals play a key role in ensuring research integrity. However, they lack the resources to conduct investigations themselves and have no mandate to sanction cheating authors. Other mechanisms to address research integrity are equally deficient in most countries. ${ }^{6}$ We need a better system to prevent, report and respond to allegations of research misconduct.
In 2010, the Council of Canadian Academies issued a report on academic integrity commissioned by the federal Minister of Industry. ${ }^{6}$ It called for the creation of a federal agency for research integrity to focus on education and prevention. It did not, however, propose new mechanisms for investigating or sanctioning misconduct. Education is, indeed, the best way to improve research integrity across the system, but as long as there are great demands and great rewards for high-impact research, it is naive to think education alone will eliminate misconduct.

A new agency, or an existing authority such as the Panel on Research Ethics, must be given the power and mandate to investigate all allegations of research misconduct, along with the authority to compel researchers to come before panels and institutions to provide access to all necessary information to exonerate or find fault. For maximum deterrence, any new authority must publish names of all individuals involved in serious misconduct, release the outcomes of all investigations and issue regular reports.

We believe this proposed agency's cost should be shared between the federal government and academic institutions. The former, because the major granting councils and the many sectors of the federal government involved in research must represent the public interest, including protecting the integrity of science and ensuring wise use of taxpayer dollars. Universities and research institutes should foot part of the bill because, as employers, they must accept responsibility for scientific misconduct by their staff.

We can't say whether any more wrongdoing would come to light under a new structure. We hope that some people would feel more comfortable taking allegations to a third party. Such an agency would be likely in any case to have better resources for investigations and satisfactorily resolve allegations in a timely manner. But its real benefit for the public and researchers alike would lie in independent and transparent public reporting. Research should not be subject to real or imagined conflicts between scientific integrity and the reputation of academic institutions.

Matthew B. Stanbrook MD PhD, Noni E. MacDonald MD MSc, Ken Flegel MDCM MSc, Paul C. Hébert MD MHSc

For references, see Appendix 1, available at www.cmaj.ca/lookup/suppl /doi:10.1503//cmaj.110442/-/DC1.

Competing interests: See www.cmaj.ca/site/misc/cmaj_staff.xhtml.

Affiliations: See www.cmaj.ca/site/misc/cmaj_staff.xhtml.

Correspondence to: $C M A J$ editor, pubs@cmaj.ca

CMAJ 2011. DOI:10.1503/cmaj.110442 